\title{
Intensity and Persistence of Soil Water Repellency in Pine Forest Soil in a Temperate Continental Climate under Drought Conditions
}

\author{
Edyta Hewelke ${ }^{1, *(\mathbb{D})}$, Lidia Oktaba ${ }^{2}$ (D), Dariusz Gozdowski ${ }^{2}\left(\mathbb{D}\right.$, Marek Kondras $^{2}$, \\ Izabella Olejniczak ${ }^{3}$ and Ewa Beata Górska ${ }^{2}$ \\ 1 Faculty of Civil and Environmental Engineering, Warsaw University of Life Sciences-SGGW, \\ Nowoursynowska 166, 02-787 Warsaw, Poland \\ 2 Faculty of Agriculture and Biology, Warsaw University of Life Sciences-SGGW, Nowoursynowska 166, \\ 02-787 Warsaw, Poland; lidia_oktaba@sggw.pl (L.O.), dariusz_gozdowski@sggw.pl (D.G.); \\ marek_kondras@sggw.pl (M.K.); e.b.gorska@wp.pl (E.B.G.) \\ 3 Institute of Ecology and Bioethics, Cardinal Stefan Wyszynski University in Warsaw, Dewajtis 5, \\ 01-815 Warsaw, Poland; iza-olejniczak@wp.pl \\ * Correspondence: edyta_hewelke@sggw.pl; Tel.: +48-22-59-35-356
}

Received: 5 June 2018; Accepted: 14 August 2018; Published: 23 August 2018

\begin{abstract}
Although soil water repellency (SWR) has been reported under different soils, climates, and vegetation types of the world, especially in forest land and following wildfires, the understanding of this variable continues to be rather limited. This study presented the characterization of SWR from wild fire measurements in a Scots pine Peucedano-Pinetum forest in the Kampinos National Park (central Poland), which is characterized by a temperate continental climate. The main objectives were: [i] To evaluate the potential occurrence, intensity, and persistence of soil water repellency in the surface layers of podzolized rusty soils during a dry summer; [ii] to determine whether a wildfire increased SWR, compared to the unburnt condition of soil; and [iii] to identify changes in hydrophobicity 13 months after a fire. The Water Drop Penetration Time (WDPT) test was used to assess persistence and intensity of soil SWR. Hydrophobicity is a natural phenomenon during periods of drought in temperate continental climates. The extreme class of SWR was observed in surface layers of up to $20 \mathrm{~cm}$. A higher hydrophobicity was noted in the older habitats of the Peucedano-Pinetum forest. Maximum WDPT values (10,800 s) were found for an older ecosystem cover, during a dry summer. SWR in fire-affected soils is dependent on the intensity of the fire, as well as displaying spatial and seasonal variability. Thirteen months after a fire, the highest variability in the occurrence of non-wettability, was recorded in the surface layers of areas affected by a weak fire. A positive relationship between soil $\mathrm{pH}$ and WDPT values was determined to a $20 \mathrm{~cm}$ depth. Prolonged dry periods resulting from global climate change, may enhance the effects of increasing SWR; it therefore seems reasonable for future research on biosphere-climate interactions, to take the presence of hydrophobicity into account.
\end{abstract}

Keywords: hydrophobicity; land surface hydrology; climate change; fire; fine sand; pozols

\section{Introduction}

Increases in the frequency and intensity of droughts are predicted to greatly affect the carbon and water cycles of the terrestrial biosphere [1], with harsh consequences to the functions and services supplied by forests [2-4]. Nearly et al. [5] raise an important issue of whether the current understanding of the linkages between forest soils and water quantity and quality, will hold up in a changing climate. 
In Reference to Goebel et al. [6], low soil moisture content, particularly in combination with high temperatures, can increase soil water repellency (SWR). By decreasing water infiltration, soil water repellency affects hydrological and ecological soil functions [7]. The effects are rather perceived as negative, i.e., increasing surface runoff and erosion, impeding plant growth, creating irregular infiltration patterns, and preferential flow in forest soils [8], as well as a redistribution of rainwater in the forest floor $[9,10]$ and in the mineral soil $[11,12]$. SWR also indirectly affects soil $\mathrm{CO}_{2}$ efflux, by exerting an influence on soil moisture distribution [13,14].

SWR is especially relevant in arid and semiarid areas, such as Mediterranean ecosystems, where water resources may be especially limited and the distribution of rainfall is strongly seasonal. SWR in Mediterranean soils has been closely related to some plant species, such as pines [15-18]. In Poland, SWR was evaluated in terms of the impact of long-term drainage on the organic soil transformation processes; and reducing the level of groundwater was found to significantly increase the occurrence of SWR [19-24].

Several studies on soil hydrophobicity in European temperate forests [25-30] have been published. SWR typically shows temporal variations, which are strongly related to the seasons [31].

Water repellency is present in some forest and shrub communities, but fire can enhance, reduce, or even create it [32]. It has been established that the severity of fire-induced SWR, depends on the burning temperature [33,34], vegetation type and land use [35-37], and soil properties [38].

The heating up of soil during a fire can create hydrophobic layers on or near the surface of the soil. The infiltration of water into the soil becomes more difficult, surface runoff is present, and the decrease in the moisture content of the soil increases preferential flow [39]. Hydrophobic layers can stimulate soil degradation processes by decreasing the soil-water relationship, at the same time causing a decrease in the fertility of soil and increasing losses of soil and water. Malkinson and Wittenberg [40] suggested that, in the short-term, fire-induced SWR dynamics are controlled by pre-fire vegetation. Bodí et al. [41] reported increased SWR immediately after burning, and a rapid decrease in the period following it, with variations strongly related to soil moisture.

However, much less is known about the natural hydrophobicity in Central Europe, and the effects that fires have on it.

Wildfires are one of the main natural disturbance factors in forest ecosystems, and are caused largely by lightning strikes [42]. Thompson et al. [43] described future opportunities and challenges, for the management of wildfire-watershed interactions in forest. Additionally, elevated temperatures and summer droughts associated with global climate change are expected to increase the intensity and frequency of wildfires [44]. Generally, wildfires are very severe, because they usually occur under dry conditions in the presence of an abundant fuel load.

The most intense reduction in the moisture supply in Central Europe was registered, for the Mediterranean Sea and the Central European region [45]. In Boczoń et al. [46], who had carried out studies in 2015, drought soil occurred in almost all of Poland's forests. Water retention characteristics and physical parameters of the forest soil in pine and spruce ecosystems across Poland, were presented by Hewelke et al. [47]. In 2015, as a result of the weather conditions in Poland, which were especially conducive to occurrence of forest fires, their number reached close to record values from the last years of the 21st century [48]. The forestation index in Poland was 29.4\% (according to GUS-Central Statistical Office-data from 31 December 2014). An unfavourable feature of Polish forests from the point of view of biological diversity, is the small variety in terms of tree species making up the forest stands. Coniferous tree stands predominate, and the percentage of pine, as the dominant species, was over 59.1\% (according to GUS-Central Statistical Office-data from 31 December 2014). Currently, there is a tendency to increase the share of other tree species, mainly deciduous ones.

Niklasson et al. [49] suggests that, due to the presence of Pinus silvestris, fire should be increasingly taken into consideration in models of disturbance, vegetation development, and forest openness in the entire Central European lowland forest region. 
The present study was conducted considering the described dependencies of hydrological consequences and related SWR processes. The first objective was to evaluate surface SWR, in forest podzolized rusty soil during a dry summer. The second was to determine whether wildfires increased SWR, compared to the unburned condition of soil. Finally, the third objective was to identify changes in hydrophobicity in a post-fire year.

\section{Materials and Methods}

\subsection{Site Characteristic and Soil Sampling}

Kampinoski National Park (KNP) is located in the valley of the central course of the Vistula River and covers an area of $385.4 \mathrm{~km}^{2}$. It was established in 1959 and has been on the list of the UNESCO Biosphere Reserves since 2000. The geological make-up, varied landform, and presence of wetlands or swampy areas with linear dunes with forest cover, are what comprise the richness of the landscape and vegetation. The most important function of the KNP is the protection of natural resources and natural processes. The proximity of Warsaw exerts strong human pressure. In the XIX century, there was a mass cutting of forests, for the purposes of settlement and agriculture. The construction of floodbanks along the Vistula and Bzura rivers significantly altered the hydrological conditions, eliminating flooded areas. The system of drainage channels constructed in the middle of the XX century, was to meet agricultural criteria, and did not account for environmental circumstances. Intensive drainage, including the drying up of swampy areas, led to the level of ground water being permanently lowered and the impoverishment of ecosystems dependant on water, leading to the partial disappearance of swampy areas and wetlands. Numerous source water intakes connected with the urbanization of areas adjacent to the KNP, further contribute to the lowering of the water table. The hydrogeological conditions are summarized in literature, e.g., References [50,51]. According to Krogulec [51], the probability of the occurrence of a full hydrogeological drought (defined as a period when the groundwater level $\mathrm{GwL} \leq 0.5 \mathrm{~m}$ ), was determined at $16 \%$ on average, for the period 1999-2013.

The unfavourable change in the hydrological conditions caused an increase in the risk of the occurrence of droughts, which in the case of forest areas, in which pines dominate, signifies increased fire risk. Kampinoski National Park is considered as being in the highest category of forest fire risk. Fires in the KNP, comprise 50\% of all forest fires in Polish national parks. Since 2013, actions have been undertaken to increase water retention in the area of the KNP, which will protect the Kampinoski swamps from summer droughts.

The study area was located within the coordinates $\mathrm{N} 52^{\circ} 20^{\prime} 36.67^{\prime \prime}-\mathrm{N} 52^{\circ} 20^{\prime} 25.53^{\prime \prime}$ and E $20^{\circ} 45^{\prime} 49.10^{\prime \prime}-\mathrm{E} 20^{\circ} 46^{\prime} 13.87^{\prime \prime}$, in the north-eastern part of the KNP. The relief in the studied area had an irregular topography, with the elevation ranging from 78.7 to 87.6 m.a.s.l. The surface was covered by a plant group of Peucedano-pinetum, which varied in age from 60 to 200 years.

The analysed area had experienced two fires: on 7 May and 4 June 2015, which covered a total area of over 11 hectares. The cause of these fires was most likely arson. They were ground fires, of which the June fire turned into a subsurface one. The layer of litter was smouldering for 3 days, making it difficult to put out. As a consequence, the surface organic layers had been largely burnt.

A network of forty-nine permanent study areas with a surface area of $100 \mathrm{~m}^{2}$ each, was set up in the burned area. In the central part of the burned area, where the organic layer had been significantly burned, 11 randomly selected areas (Central Fire) were set up. The second group of areas was located in pairs, along the border of the burned area, every $80 \mathrm{~m}$, on the burned side where the organic layer had been slightly burned (Peripheral Fire); and on the side not affected by the fire (Control)—encompassing a total of 38 areas.

Soil samples were collected from six randomly selected points for each area, and a collective sample prepared for each of the three mineral layers, i.e., $0-5 \mathrm{~cm}, 5-10 \mathrm{~cm}$, and $10-20 \mathrm{~cm}$. Soil samples were collected in two periods, i.e., between the 17 and 24 July 2015-a month after the fire, and between the 15 and 20 July 2016-13 months after the fire. In July 2015, samples were taken from the selected 
areas, and in 2016, 11 areas in each of the three zones of the burned region selected. 147 and 99 soil samples, were collected in 2015 and 2016, respectively. Fewer research areas were designated in 2016 than in 2015, because part of the north edge of the burned area was excluded, due to a protection zone of the black stork's nesting grounds (Ciconia nigra).

\subsection{Soil Properties}

To identify soil properties, 11 areas of each site, i.e., Central Fire, Periferial Fire, and Control in 2015 and 2016 were used. From the three soil layers in each area, disturbed samples were collected to be measured for total organic carbon (TOC), soil $\mathrm{pH}$, and particle size distribution. Total organic carbon was measured by a non-dispersive infrared method, using a Shimadzu TOC-V analyser with a solid-sample module (Shimadzu TOC 5000 A); nitrogen level was determined using the Kjeldahl method (analyser Kjeltec-Tecator); while soil pH in $\mathrm{H}_{2} \mathrm{O}$ and in $1 \mathrm{~m} \mathrm{KCl}$ was measured potentiometrically. Particle size distribution was performed using the Bouyoucos method, with modifications by Casagrande and Prószyński (the aerometric method) for particles smaller than $0.1 \mathrm{~mm}$, and the sieve method for particles larger than $0.1 \mathrm{~mm}$, according to Reference [52]. Soil formations, which the analysed podzolized rusty soils had formed from are well-sorted eolic sands, with a granulation of fine sand, according to the United States Department of Agriculture (USDA) classification [53]. They are characterized by a very large percentage share of the sand fraction, of approximately $90 \%$. Silt and clay fractions are found in trace amounts.

The soils were classified as Albic Brunic Arenosol and Brunic Arenosol, according to the IUSS Working Group WRB [54]. Soil humus was classified as a moder-mor type.

\subsection{Meteorological Conditions}

Daily meteorological data (precipitation, air temperature and humidity, wind speed, and hours of sunshine) were recorded at the Granica-KPN station ( $52^{\circ} 17^{\prime} 10^{\prime \prime}$, E $20^{\circ} 27^{\prime} 16^{\prime \prime}$, elevation $73 \mathrm{~m}$ a.s.1.), which is located near the site of the investigation. The metrological data used have been collected since 1994. Groundwater levels were measured at the interval of a fortnight by the nearest piezometer (N 52 $34^{\prime} 13.7^{\prime \prime}$, E $20^{\circ} 75^{\prime} 32.5^{\prime \prime}$ ), starting in November 1999.

Monthly precipitation amounts, mean temperatures, and ground water levels during the two hydrological years, as well as long-term averages, have been presented in Figure 1. Temperatures registered in the hydrological years 2015 and 2016 (Figure 1a), turned out to be higher than the averages from the 1994-2014 multi-year period, by $0.7^{\circ} \mathrm{C}$ and $1.0^{\circ} \mathrm{C}$, respectively. The year 2015 was a slightly warm $\left(9.4^{\circ} \mathrm{C}\right)$, and dry $(419 \mathrm{~mm})$ year. The occurrence of a meteorological winter was not noted. Not in any of the months did the average temperature fall below $0{ }^{\circ} \mathrm{C}$, and snowfalls were not observed. 2016 was a warm year $\left(9.7^{\circ} \mathrm{C}\right)$ and normal, in terms of atmospheric precipitation $(580.5 \mathrm{~mm})$. It was characterized by a very short winter. Only in January did the average air temperature fall below $0{ }^{\circ} \mathrm{C}$. Starting in April 2015 (Figure 1b), the lowering of ground water levels was observed in reference to the average, from the multiannual period (1994-2014), and this tendency persisted for subsequent months. In July 2015, this difference was $15 \mathrm{~cm}$, in February 2016 it was over $40 \mathrm{~cm}$, and in July $2016-18 \mathrm{~cm}$. The year 2016 was another year during which the lowering of values of ground water levels was observed, and in the case of surface waters, a significant low-water period occurred [55]. Krogulec's [51] investigation showed that hydrogeological droughts, characteristic of the summer months, occur only during the years when the lowest groundwater levels are observed. 
a)

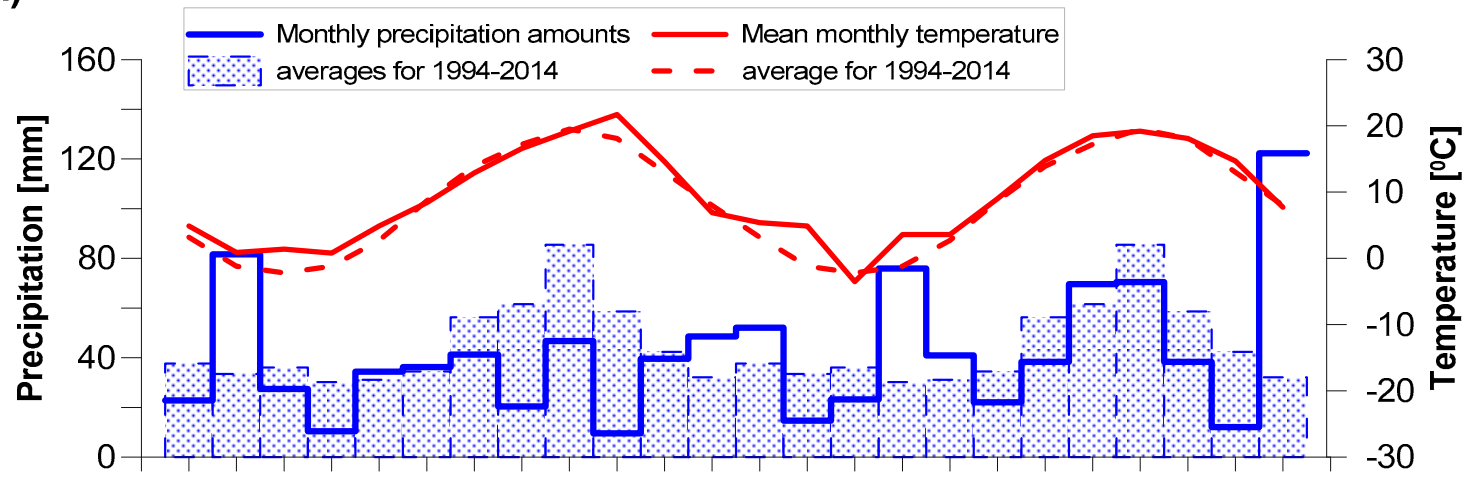

b)

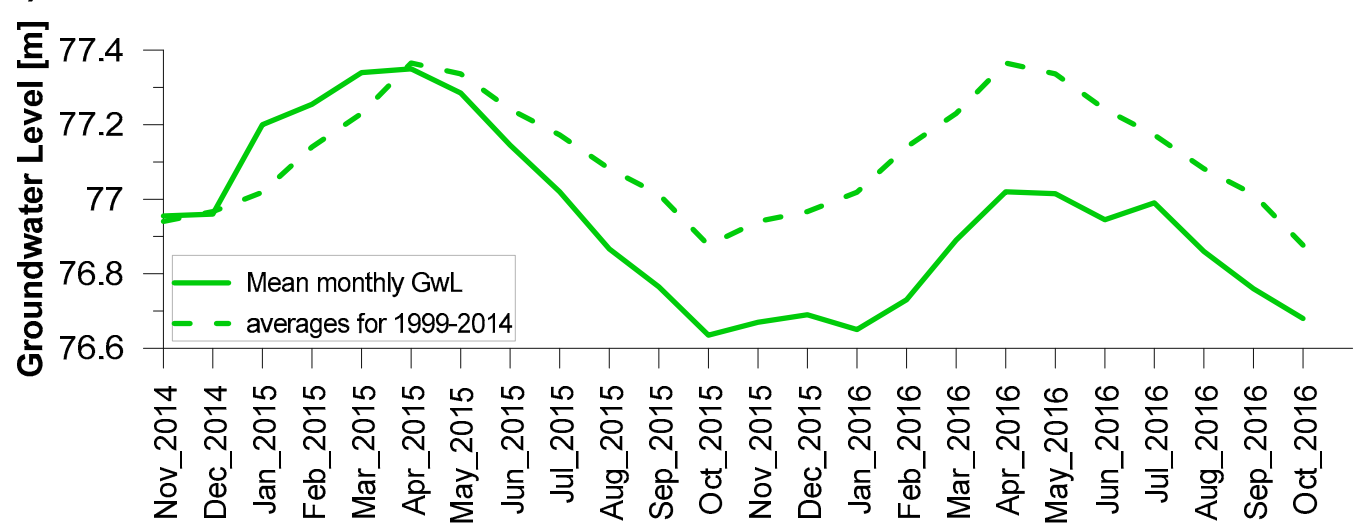

Figure 1. Monthly precipitation amounts, monthly mean temperature (a) and ground water level (b) during the study period along with averages from the years 1994 to 2014-precipitation and temperature, and 1999 to 2016-ground water level, respectively.

\subsection{Assessment of SWR}

The soil water repellency of each soil sample was determined using the WDPT test, which, in addition to being the most suitable [56] and most widespread method, is relatively simple $[7,12,57]$. All 147 soil samples in 2015, and 99 soil samples in 2016, were dried at room temperature $\left(20^{\circ} \mathrm{C}\right)$ to a constant weight. About $20 \mathrm{~g}$ of each sample was placed in Petri dishes and drops of distilled water from a standard medicine dropper, were deposited on the smoothed soil sample. As less research areas were designated in the field in 2015, laboratory tests were extended. In 2015, five drops were placed on each soil sample, while in 2016, sixteen drops were used. Values of the WDPT test were used for statistical analysis and the results were used to establish SWR classes, according to the classification proposed by Dekker \& Jungerius [58]. The following five SWR classes were distinguished: (0) wettable or non-water repellent, WDPT $<5 \mathrm{~s}$; (1) slightly repellent, from $5 \mathrm{~s}$ WDPT $\leq 60 \mathrm{~s}$; (2) strongly repellent, from 60s WDPT $\leq 600 \mathrm{~s}$; (3) severely repellent, from 600s WDPT $\leq 3600 \mathrm{~s}$; and (4) extremely repellent, WDPT $>3600 \mathrm{~s}$.

\subsection{Statistical Analysis}

Since WDPT test values do not follow a normal distribution, its results were subjected to non-parametric statistical analysis using the Kruskal-Wallis test, for each year. WDPT test results for control, peripheral fire, and central fire areas were evaluated by statistical tests in comparisons conducted separately for each year. Statistical tests were conducted on the sub-datasets, for each soil layer $(0-5,5-10$, and $10-20 \mathrm{~cm}$ of depth). 
After obtaining a significant Kruskal-Wallis test result, the Mann-Whitney U-test was conducted to compare central year-to-year tendencies, between each area and depth. Statistical analysis using the Mann-Whitney U-test, was conducted to compare central tendencies in WDPT test values between the two age groups of ecosystems at different areas and depths, for each year, separately. Significance statements in the text refer to two-tailed probability values obtained, for the Kruskal-Wallis and Mann-Whitney tests. Median values were adopted as the central tendency in each of the statistical analyses carried out and used to establish SWR classes.

Spearman's rank correlation coefficient was used to provide information about the chemical properties of soil, and median WDPT relationships. All statistical analyses were carried out using the Statistica 13 statistical software-package.

\section{Results}

\subsection{Soil Chemical Properties}

Directly after the fire (July 2015), significant diversification in the total organic carbon (TOC) contents was determined in the surface layer of the soil $(0-5 \mathrm{~cm})$, between the analysed areas (Table 1). For the area of the central fire, the content of TOC was the lowest and amounted to $2.26 \%$ and $2.24 \%$, respectively.

Table 1. Selected properties of soil, mean values $(n=11)$ with SD in brackets. TOC—total organic carbon, $\mathrm{N}$-nitrogen, $\mathrm{pH}$-acidity.

\begin{tabular}{|c|c|c|c|c|c|c|c|}
\hline $\begin{array}{l}\text { Sampling } \\
\text { Time }\end{array}$ & Site & $\begin{array}{l}\text { Soil Depth } \\
\text { (cm) }\end{array}$ & TOC (\%) & N (\%) & $\mathrm{C} / \mathrm{N}$ & $\begin{array}{c}\mathrm{pH}\left(\mathrm{H}_{2} \mathrm{O}\right) \\
{[-]}\end{array}$ & $\begin{array}{c}\mathrm{pH}(\mathrm{KCl}) \\
{[-]}\end{array}$ \\
\hline \multirow{9}{*}{ July 2015} & \multirow{3}{*}{$\begin{array}{l}\text { Central } \\
\text { Fire }\end{array}$} & $0-5$ & $1.51(0.54)$ & $0.068(0.016)$ & $23.38(9.70)$ & $3.55(0.26)$ & $3.39(0.28)$ \\
\hline & & $5-10$ & $1.25(0.38)$ & $0.053(0.017)$ & 25.07 (10.34) & $3.57(0.17)$ & $3.48(0.25)$ \\
\hline & & $10-20$ & $0.63(0.11)$ & $0.044(0.022)$ & $16.49(5.73)$ & $3.90(0.18)$ & $3.78(0.28)$ \\
\hline & \multirow{3}{*}{$\begin{array}{l}\text { Peripheral } \\
\text { Fire }\end{array}$} & $0-5$ & $2.28(0.65)$ & $0.096(0.023)$ & $24.17(6.28)$ & $3.44(0.21)$ & $3.15(0.22)$ \\
\hline & & $5-10$ & $1.29(0.24)$ & $0.058(0.057)$ & $23.6(6.22)$ & $3.59(0.15)$ & $3.39(0.22)$ \\
\hline & & $10-20$ & $0.61(0.19)$ & $0.041(0.014)$ & $17.20(7.23)$ & $3.95(0.27)$ & $3.79(0.28)$ \\
\hline & \multirow{3}{*}{ Control } & $0-5$ & $2.24(0.65)$ & $0.097(0.026)$ & $23.57(5.21)$ & $3.29(0.24)$ & $3.02(0.13)$ \\
\hline & & $5-10$ & $1.26(0.23)$ & $0.067(0.019)$ & 19.69 (4.62) & $3.42(0.15)$ & $3.27(0.22)$ \\
\hline & & $10-20$ & $0.56(0.17)$ & $0.045(0.017)$ & $15.08(7.43)$ & $3.96(0.12)$ & $3.79(0.17)$ \\
\hline \multirow{9}{*}{ July 2016} & \multirow{3}{*}{$\begin{array}{l}\text { Central } \\
\text { Fire }\end{array}$} & $0-5$ & $1.85(0.68)$ & $0.038(0.014)$ & $50.00(9.37)$ & $3.21(0.17)$ & $3.07(0.16)$ \\
\hline & & $5-10$ & $1.39(0.52)$ & $0.029(0.010)$ & 49.08 (14.33) & $3.48(0.17)$ & $3.25(0.14)$ \\
\hline & & $10-20$ & $0.83(0.22)$ & $0.019(0.006)$ & $43.41(6.54)$ & $3.92(0.15)$ & $3.70(0.13)$ \\
\hline & \multirow{3}{*}{$\begin{array}{l}\text { Peripheral } \\
\text { Fire }\end{array}$} & $0-5$ & $2.16(0.68)$ & $0.048(0.014)$ & $45.17(6.40)$ & $3.70(0.14)$ & $3.56(0.14)$ \\
\hline & & $5-10$ & $1.48(0.37)$ & $0.034(0.009)$ & $43.57(7.46)$ & $3.94(0.15)$ & $3.76(0.17)$ \\
\hline & & 10-20 & $0.93(0.26)$ & $0.022(0.007)$ & 45.41 (12.73) & $4.46(0.30)$ & $4.22(0.24)$ \\
\hline & \multirow{3}{*}{ Control } & $0-5$ & $2.47(0.75)$ & $0.057(0.021)$ & $43.87(5.83)$ & $3.59(0.35)$ & $3.29(0.25)$ \\
\hline & & $5-10$ & $1.57(0.47)$ & $0.037(0.015)$ & $44.25(9.77)$ & $3.85(0.36)$ & $3.47(0.24)$ \\
\hline & & $10-20$ & $0.89(0.26)$ & $0.023(0.007)$ & $40.96(12.50)$ & $4.37(0.30)$ & $3.90(0.30)$ \\
\hline
\end{tabular}

A year later (July 2016), the average content of TOC in the area of the central fire increased to $1.85 \%$ in the $0-5 \mathrm{~cm}$ layer, which may have signified the beginning of its biological regeneration.

The highest variation (SD) in TOC content, was observed in all analysed areas in the 0-5 cm layer. Average values of TOC, for the 5-10 cm and 10-20 cm layers, did not reveal large variation between the analysed surfaces, both in the first, as well as in the second, measurement period (Table 1).

The effect of fire on soil organic matter content is highly dependent on, among other factors, the type and intensity of the fire, soil moisture, soil type, and the nature of the burned materials [59]. Depending on the nature of the fire, the amount of organic carbon in the soil can be higher or lower, than immediately after the fire. In addition to the amount, the nature of the carbon compounds also changes. In the area which underwent a fire in the central part, the contents of organic matter in the surface layers of the soil, were approximately 33\% and 28\% lower in 2015 and 2016, respectively, than 
in the control surfaces. These differences were limited to the surface layers $0-5 \mathrm{~cm}$, as confirmed by the findings of Badia et al. [60].

In July 2015 , the lowest contents of nitrogen, i.e., $0.068 \%$ on average, were observed in the surface layer of the soil $(0-5 \mathrm{~cm})$, in the area of the central fire. At the same time, in the areas of the peripheral fire and the control areas, the average contents of nitrogen were higher, amounting to 0.096 and 0.097 , respectively. Nitrogen content in the soil decreased along with depth, both in the area of the central and peripheral fire, as well as the control. In an analogical period of 2016, a decrease in nitrogen content by approximately $50 \%$ in all of the analysed surfaces and in all layers, was observed. At the same time, a significant increase in the $\mathrm{C}: \mathrm{N}$ relationship took place. It ought to be highlighted that the drought in 2016, was followed by a warm winter. February and March 2016, were characterized by more abundant rainfalls, ensuring favourable conditions for microbiological activity and plant growth. These circumstances facilitated the initiation of the biological regeneration of the area touched by the fire.

The soil $\mathrm{pH}$ varied depending on the depth and time of collecting the soil samples (Table 1). Average values of $\mathrm{pH}$, were the lowest at both measurement periods of the study in the surface layers (at a depth of 0-5 cm) and fell into the ranges of 3.21 to 3.70 (for $\mathrm{pH}$ in $\mathrm{H}_{2} \mathrm{O}$ ), and 3.02 to 3.56 (for $\mathrm{pH}$ in $\mathrm{KCl}$ ). An increase in $\mathrm{pH}$ was observed, along with the depth of soil sample collection, from 3.21 to 4.46 (for $\mathrm{pH}$ in $\mathrm{H}_{2} \mathrm{O}$ ) and from 3.02 to 4.22 (for $\mathrm{pH}$ in $\mathrm{KCl}$ ). Average values of $\mathrm{pH}$ in $\mathrm{H}_{2} \mathrm{O}$ and $\mathrm{pH}$ in $\mathrm{KCl}$ in 2015, differed insignificantly between the surfaces, though slightly higher values were confirmed in the areas of the central fire. Greater differences between the areas were observed a year after the fire. A slight decrease in $\mathrm{pH}$ values (in $\mathrm{H}_{2} \mathrm{O}$ and in $\mathrm{KCl}$ ), was noted in areas of the central fire, contrary to the increase noted in areas of the peripheral fire, and a slightly lower one in the control areas.

Immediately after the fire, the $\mathrm{pH}$ differences between the central part of the fire and peripheral fire, as well as the control, were noticeable mainly in the surface $5 \mathrm{~cm}$ layer of the soil. A similar phenomenon was confirmed by Molla et al. [61]. The highest $\mathrm{pH}$ in the year 2015, was noted in areas of the central fire, though it ought to be noted that the differences between the analysed areas immediately after the fire were small. This is, however, in agreement with data found in literature and connected with the release of basic components into the environment, and the possible formation of carbonates and alkali metal oxides [62].

In 2016, a decrease in $\mathrm{pH}$ was confirmed in the areas of the central fire, contrary to the increase observed in the area of the peripheral fire, and in control areas. The increase of $\mathrm{pH}$ has implications for nutrient availability, soil respiration, microbial activity, mineralization rates, and plant germination.

\subsection{Persistence of Potential SWR}

Significant differences in WDPT test values were observed amongst the $0-5 \mathrm{~cm}, 5-10 \mathrm{~cm}$, and 10-20 cm layers (Kruskal-Wallis test, and upper and lower quartiles) at two measurement periods (Figure 2). In July 2015 (Figure 2a), the 0-5 cm, 5-10 cm, and 10-20 cm layers in the control area and in the area of the peripheral fire did not differ significantly, and were classified as severely repellent for surface layers, and strongly repellent for the level of 10-20 cm. On the other hand, the results from the area of the central fire differed significantly from both the control, as well as the peripheral fire, as well as in each of the analysed layers, and were classified as the highest, extremely repellent class (median WDPT values were more than 3600s).

It ought to be highlighted that the obtained results for the area of the control and peripheral fire were similar, which may have signified that both the drying out of the surface layer of the soil as a result of the present meteorological conditions, as well as a peripheral fire of lower intensity than in the central part, had a similar influence on the occurrence of the phenomena of hydrophobicity. The fire in the central part, on the other hand, was stronger, and the organic layer of the soil (litter) was severely damaged, significantly raising the hydrophobicity class in even the 10-20 cm layer (difference of two classes, as compared to results obtained from the control area and the peripheral fire). 
a)

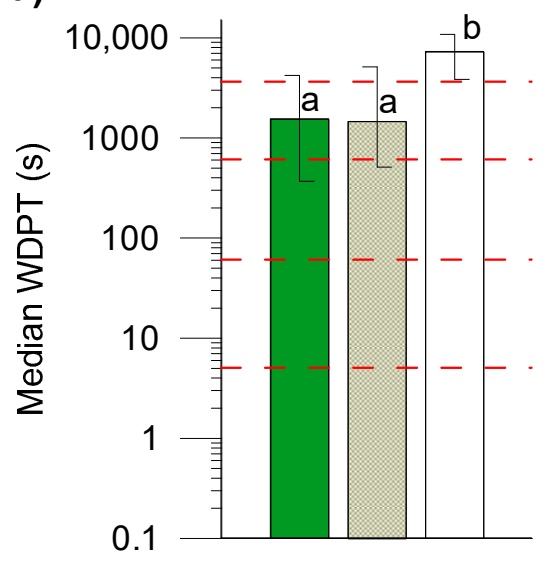

b)

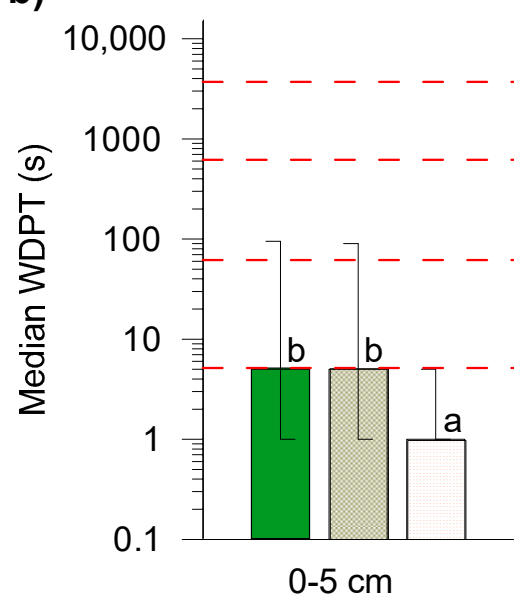

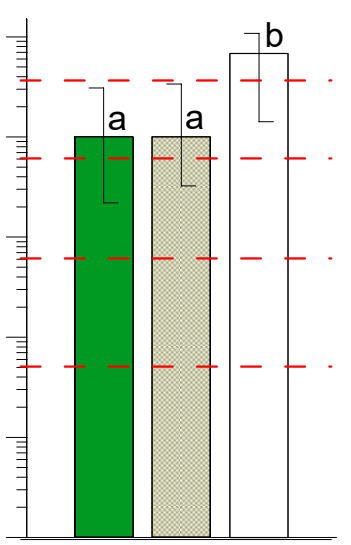

$5-10 \mathrm{~cm}$

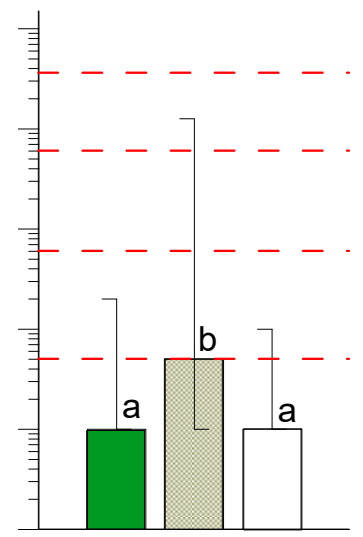

$5-10 \mathrm{~cm}$

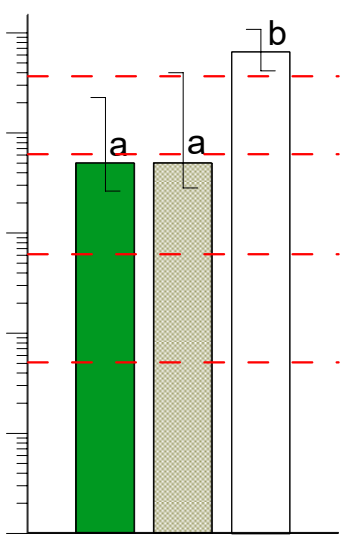

$10-20 \mathrm{~cm}$

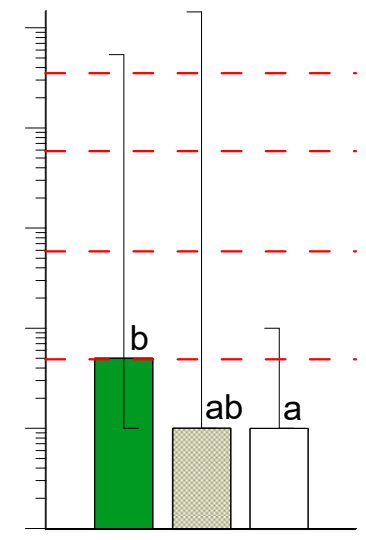

$10-20 \mathrm{~cm}$

Control $\square$ Peripherial Fire $\square$ Central Fire $\quad$ Upper and lower quartiles

Figure 2. Median Water Drop Penetration Time (WDPT) with upper and lower quartiles on the control site, and in the areas of a peripheral fire and central fire in three soil depths (a) 1 month after a fire; (b) 13 months after a fire. Note: Different letters denote significant differences in each depth, as determined with the Kruskal-Wallis test $(\alpha<0.05)$. SWR classes (red dashed lines), (0) wettable or non-water repellent, WDPT < $5 \mathrm{~s}$; (1) slightly repellent, from $5 \mathrm{~s}$ WDPT $\leq 60 \mathrm{~s}$; (2) strongly repellent, from 60s WDPT $\leq 600 \mathrm{~s}$; (3) severely repellent, from 600s WDPT $\leq 3600 \mathrm{~s}$; and (4) extremely repellent, WDPT $>3600 \mathrm{~s}$.

In July 2016, 13 months after the fire (Figure 2b), lower values of the wettability classes could be observed. The medians of the WDPT test obtained for all areas in all of the layers, allowed them to be classified as SWR class 0, i.e., wettable. The results in the surface layer of $0-5 \mathrm{~cm}$ from the control area and area of the peripheral fire were statistically similar, whereas in relation to the area of the central fire-the difference was statistically significant. The greatest scope of changes in hydrophobicity, which covered all classes of wettability, was observed in the $10-20 \mathrm{~cm}$ layer in the area of the peripheral fire and the control. The 5-10 $\mathrm{cm}$ layer in the area of the peripheral fire, was also characterized by a high variability of hydrophobicity (range of changes from 0 to 3 SWR class).

\subsection{Year-to-Year Differences in Soil Water Repellency}

The medians of results from the WDPT test, as well as their comparisons, based on the Mann-Whitney statistical test for the analysed dates, have been presented in Figure 3. In the case of all surfaces and layers, statistically significant differences between two measurement periods 
were confirmed, which supports the reports regarding seasonal changes in SWR, as described in References [63-65]. Significantly higher values were confirmed in the year 2015, one month after the fire. The occurrence of hydrophobicity in the central area of the fire turned out to be the highest, i.e., extremely repellent class, in 2015 in all of the analysed layers, whilst in 2016-the lowest, i.e., wettable class.

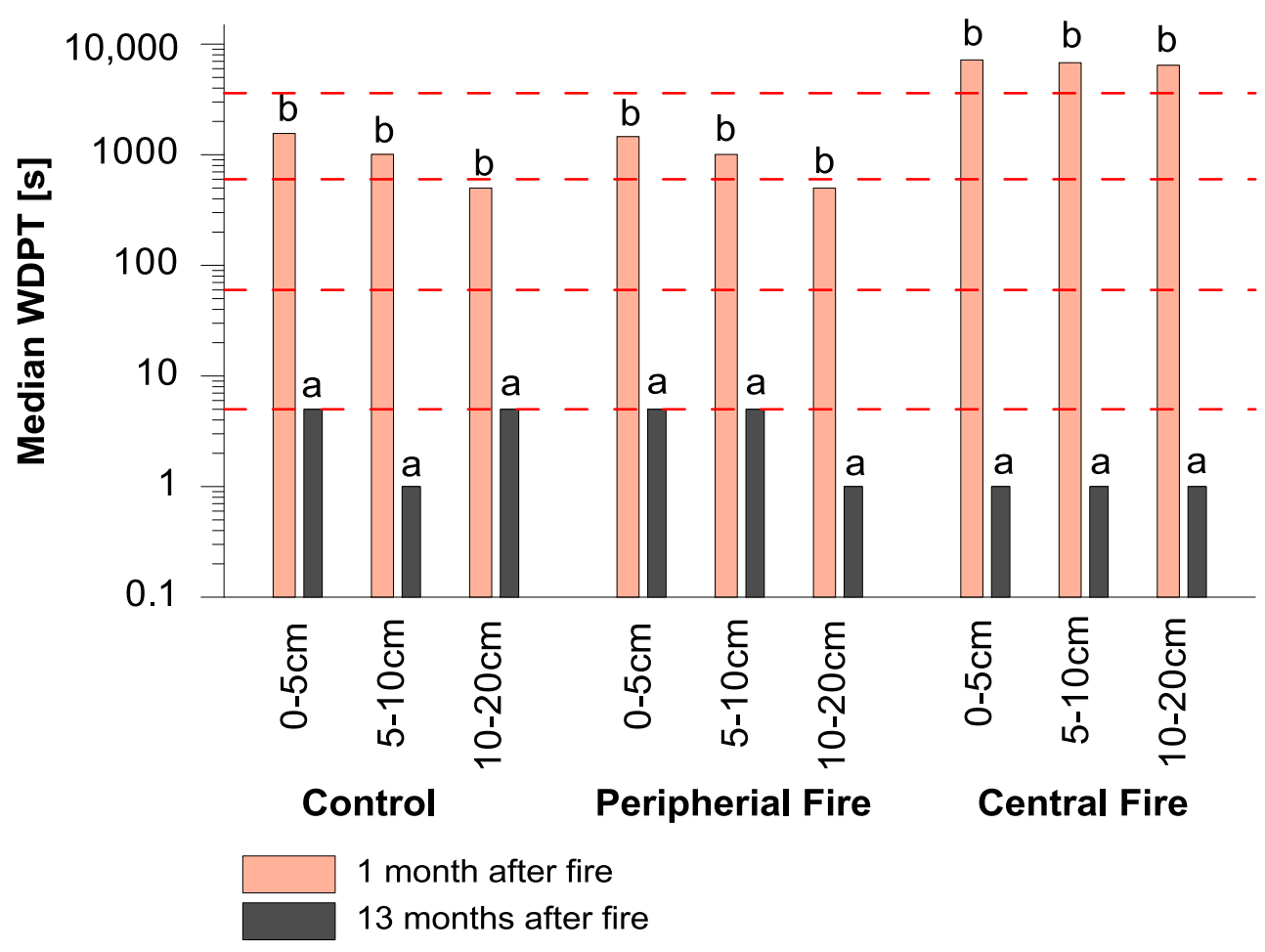

Figure 3. Median WDPT values of $0-5 \mathrm{~cm}, 5-10 \mathrm{~cm}$, and 10-20 cm soil samples of control site, peripheral fire site, and central fire site, 1 month and 13 months after the fire. The different letters denote significant differences in the sampling period, as determined by the Mann-Whitney test $(\alpha<0.01)$. The dashed lines denote SWR classes.

\subsection{SWR in Relation to the Age of the Scots Pine Forest}

The results of soil hydrophobicity were subjected to analysis, in regard to the age of the trees covering the analysed area. Two ecosystems were distinguished, i.e., a younger one-represented by a pine stand 60-90 years old, and an older one-on surfaces covered by a pine stand 170-200 years of age. Median values of the WDPT test, for soil under the two age groups of the pine stand at two measurement periods, were compared using the Mann-Whitney test (Figure 4).

The soil found under the old stand of the Peucedano-pinetum site demonstrated higher classes of SWR, both one month, as well as 13 months after the fire, as compared to the results obtained for soils under the younger stand of trees. One month following the fire, a statistically significant relationship between the results of soil hydrophobicity under the sites of the two age groups was confirmed in all layers, in both the control area and area of the peripheral fire. For sites under younger trees in the areas of the control and peripheral fire, the occurrence of class 2 of hydrophobicity (strongly repellent) was determined, whilst soil under sites with older trees was characterized by higher unwettability, classified as class 3 (severely repellent) and 4 (extremely repellent). Statistically significant differences in the WDPT test, in areas from the central part of the burned area were not noted between the soil under stands of different ages. This means that the fire in this part, contributed to the occurrence of class 4 soil hydrophobicity (extremely repellent), irrespective of the age of the trees. 
a)

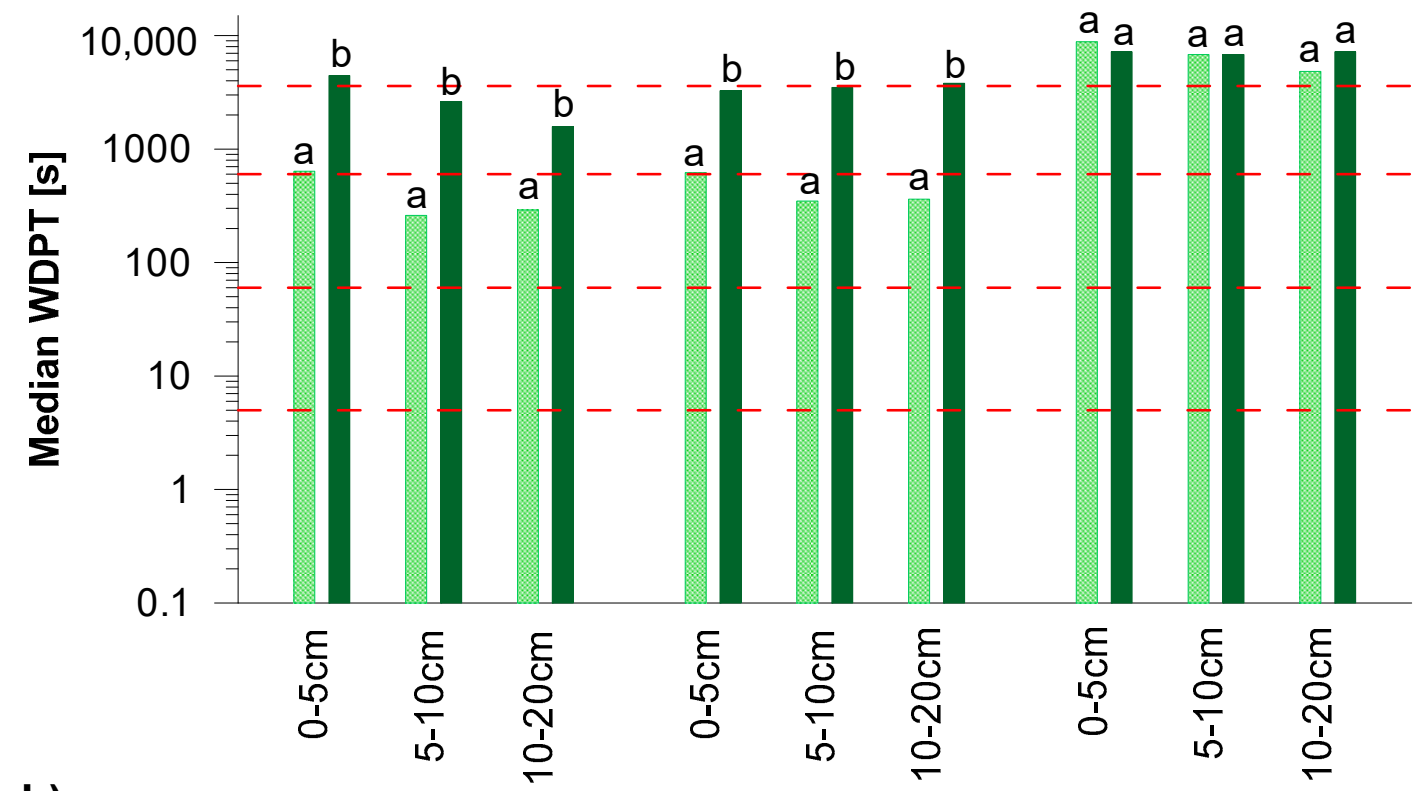

b)

Control

Peripherial Fire

Central Fire

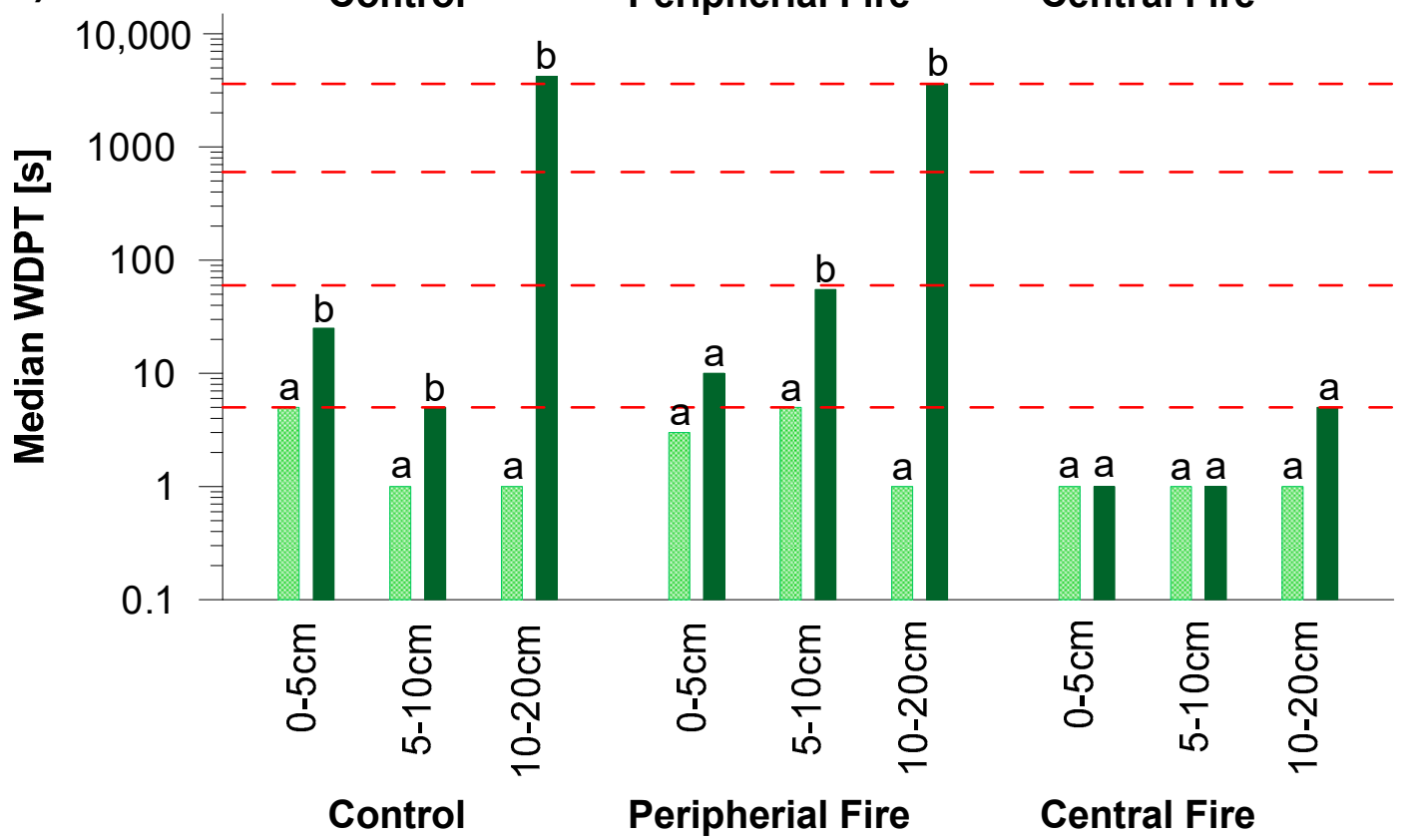

Figure 4. Median WDPT values for soil under a young and old pine stand for 0-5 cm, 5-10 cm, and 10-20 cm soil samples taken from the control site, peripheral fire site, and central fire site, (a) 1 month after the fire and (b) 13 months after the fire. The different letters denote significant differences in pine stand samples, determined by the Mann-Whitney test $(\alpha<0.05)$. The dashed lines denote SWR classes.

Thirteen months after the fire, a statistically significant relationship was confirmed between the intensity of hydrophobicity of soil under sites with various ages of trees, in all layers from the area of the control fire, as well as in layers $5-10 \mathrm{~cm}$ and $10-20 \mathrm{~cm}$ of the peripheral. In the areas of the central fire, the occurrence of Class 0 (wettable) was confirmed under all sites, regardless of the age of the stand. The highest class (extremely repellent), was obtained for the 10-20 cm layer, in areas of the control and peripheral fire under the old stand. The deposit of organic matter in the soil on sites with older trees, its decomposition and penetration into deeper layers of the soil profile, along with rain, 
under conditions of the permanent drying out of subsurface layers, is the most likely cause for such high unwettability. Keeping in mind the decrease in the level of the groundwater table in the analysed time period (Figure 1), the drying of this layer occurred, which will most likely lead to the occurrence of an unstable wettability front.

\subsection{Relation SWR to Soil Chemical Properties}

Data from literature $[7,30,66]$ shows that the presence of certain compounds, which are a component of organic matter, is responsible for hydrophobicity. In the present studies, a correlation between the amount of organic carbon and hydrophobic properties was not confirmed; however, the nature of the humic compounds occurring in the soils of the analysed areas ought to be analysed.

Significant correlations were only obtained for the dependence of repellence, on the acidity of the soil (Table 2). The $\mathrm{pH}(\mathrm{KCl})$ exhibited a positive correlation with the median WDPT test (Spearman coefficient from 0.345 to $0.395, p<0.05$ ), for all of the analysed depths of soil in 2015, and surface $5-10 \mathrm{~cm}$ in July 2016. The following processes may serve as confirmation of the positive relationship, in only the surface layers in July 2016. Firstly, ash characterized by alkaline properties, derived from the burning of organic matter in the central area, is easily blown away by wind and carried over into nearby areas. The erosion of soil after a fire is also a frequent phenomenon [32,67]. Lush vegetation developed in burned areas, which, using alkaline components, could have contributed to lowering the $\mathrm{pH}$. Furthermore, nitrogen from the burned matter changes into ammonium forms, which, because of the nitrification process, are transformed into nitrates. As a result of this process, the acidification of soil takes place.

Table 2. Spearman's rank correlation coefficients between median WDPT test value $(n=33)$ and the $\mathrm{pH}(\mathrm{KCl})$ of soil at $0-5 \mathrm{~cm}, 5-10 \mathrm{~cm}$, and $10-20 \mathrm{~cm}$ depths in two sampling periods. Only significant coefficients are shown $(p \leq 0.05)$.

\begin{tabular}{cclc}
\hline Sampling Period & Soil Depth $(\mathbf{c m})$ & & pH (KCl) $[-]$ \\
\hline \multirow{3}{*}{ July 2015 } & $0-5$ & WDPT_med. & 0.393 \\
& $5-10$ & WDPT_med. & 0.395 \\
& $10-20$ & WDPT_med. & 0.345 \\
\hline \multirow{2}{*}{ July 2016 } & $0-5$ & WDPT_med. & 0.358 \\
& $5-10$ & WDPT_med. & - \\
& $10-20$ & WDPT_med. & - \\
\hline
\end{tabular}

\section{Discussion}

For the most part, soils showed higher hydrophobicity in the surface layers and reduced hydrophobicity in the deeper layers, due to the reduction of soil organic matter [68]. In the research of Huffman et al. [69], only a few sites exhibited much hydrophobicity in the 9-18 cm layer. MacDonald and Huffman [39] found SWR to be the strongest in sites which had been burned at high and moderate severity, decreasing with increasing depth $(0-18 \mathrm{~cm})$, and be spatially highly variable. Granged et al. [36] concluded that SWR was usually higher at the soil surface, where the presence of hydrophobic substances is common after low-intensity burning, and decreased with depth; however, they did not show significant differences between soils which had not been burnt for a long time, and unburnt soils under pines. The strongest SWR under thicker layers of litter, was reported by Buczko et al. [25,26] in non-burned layers 10-40 cm in depth, and in Dekker and Ritsema [12]—for sandy soils. The explanation suggested by Buczko et al. [25] regarding this tendency, is that it is caused by the changing chemistry of the soil organic matter, along with depth and/or varied bonding of this organic matter to the soil particles. In Ganz et al. [70], the existence of SWR is not, as it is often assumed, restricted to humic topsoil, but, in sandy soil, the persistence of water repellency increases with depth. 
SWR in studies of Zavala et al. [37] (soil under pine forest after a wildfire) was only higher at the soil surface, where the presence of hydrophobic organic substances is normal after burning, and the severity of water repellency decreased along with an increase in depth of up to $40 \mathrm{~cm}$. Generally, hydrophobicity in fire-affected regions with a Mediterranean climate has often been reported under pine forests, but studies have generally been confined to the topsoil's, i.e., up to $5 \mathrm{~cm}$ deep $[60,71]$.

Results contained in this study were supported by the reports of Rodríguez-Alleres et al. [63], carried out in NW Spain, regarding the persistence of water repellency in the zone burnt by a low-severity fire and the unburnt zone, with extreme repellency classes up to $20 \mathrm{~cm}$ depth, and moderate values from 20 to $40 \mathrm{~cm}-15$ months after the fire. In Portugal [72], hydrophobicity was found to be characteristic of soils from the surface down to the weathered horizon, rather than being confined to the near-surface layer in forest areas characterized by a different burning history, and Pinus pinaster plantations. The values of non-wettability presented in the mentioned studies, were higher than WDPT $>6 \mathrm{~h}$ and WDPT $>5 \mathrm{~h}$, respectively. The high water repellency of soils under P. pinaster cover of Mediterranean regions, can be ascribed to the temperate-humid climate of the region, which favours biomass production, the presence of large amounts of organic matter, and as a result, the substantial production of hydrophobic substances [73].

The severity of a fire controls the intensity and depth of SWR in soils. According to the findings of De Bano [33] and Certini [62], an increase in burning temperature increases hydrophobicity (due to the volatilization of organic hydrocarbons), and a burn temperature of $260-280^{\circ} \mathrm{C}$ (the combustion of aliphatic compounds) reduces SWR. Most likely, the three-day fire reached deeper in the central part of the burned area and achieved higher temperatures than the fire in the peripheral areas, or in studies presented by Huffman et al. [69] and Granged et al. [36]. On the other hand, the extreme class of hydrophobicity in the central area of the fire, reveals that the temperature of the fire did not reach $260{ }^{\circ} \mathrm{C}$.

In Butzen et al. [74], who carried out studies on coniferous forest sites in Germany, water repellency effects were an important factor triggering overland flow generation. SWR increases were detected as a result of a wildfire and dry period and their persistence may contribute, in the short-term period, to higher runoff and risk of erosion over time [75]. The results of studies from July 2015, revealing high hydrophobicity in the surface layers, may also lead to similar hydrological reactions.

The occurrence of a severely repellent and extremely repellent class and high spatial variability of SWR in the 10-20 cm layer in July 2016, as well as in the higher layer, i.e., 5-10 cm, under older trees, may cause an unstable wetting front; this in turn could potentially result in preferential flow. The heterogeneity of SWR under dense pine forests, reflects the existence of wetting and water repellent three-dimensional soil patches. When SWR is enhanced by low intensity burning, infiltration is controlled by preferential flow [37]. One must also account for the quality of organic matter and its decomposition. This is the most likely cause behind the occurrence of higher non-wettability, under an older stand of trees. The high spatial variability of SWR in peripheral and control sites, may lead to the loss of nutrients, due to the washing of soluble substances by preferential flow pathways [76], thereby affecting the spatial soil water content distribution, and hence, the recovery of plant growth [77]. The influence of seasonal weather fluctuations plays an important role, highly influencing soil properties [60]. These differences in heterogeneity between the two analysed periods, may be related to the different resistance of the soil and intensity of the fire, to the breaking of SWR.

More than likely, the fire in the central part contributed to substances which were mostly associated with certain plant species, with tissues rich in resins and waxes, such as pines [78], being burned out, and wettability was noted in all analysed layers 13 months after the fire.

A different reaction to the intensity of the occurrence of a fire was also confirmed by the studies of Olejniczak et al. [79], regarding reproduction in the population of microorganisms and mesofauna in this area, 15 months after a fire. A fire of low severity affects microorganisms and mesofauna more selectively, than a severe one. Zaniewski and Otręba [80], also observed two processes by which vegetation responded in this burned area in 2016. The first, classified as regeneration with an increase 
in the richness of forest species, occurred in peripheral plots. The second process was defined as similar to secondary succession, where non-forest species occurred on the highest burnout in central plots.

The results of the research indicated that the intensity of a fire, can be one of the factors affecting soil and biogeochemical processes. Soils are multi-scale complex systems, with long-lasting resilience, as well as rapid response.

Frequent occurrence of wetting and drying events, common to the temperate continental climate, is associated with the seasonal changing of SWR. When soil is exposed to longer dry spells, it becomes severely and extremely water-repellent. Seeing as how the hydrological consequences of variable SWR distribution are unique, it is necessary to recognise their distinctiveness from entirely wettable or water-repellent soils. The studies carried out, prove that changes in the occurrence of SWR are also present in deeper layers of forest soil in central Poland, and thus, its consequences ought to be studied in the subsurface layers as well.

The assessment of the natural range of groundwater level fluctuations, can assist in effecting better local water resource management, and reducing the risk of groundwater drought hazard and occurrence. The assessment of SWR persistence in the soil profile, on the other hand, may improve our understanding of sustainable groundwater resource management.

Bearing in mind that dry periods in late spring and summer are expected to become more frequent [81], the probability of the occurrence of the phenomenon of hydrophobicity in Central European forests is increasing.

\section{Conclusions}

With regard to our observations, SWR is a natural phenomenon, which occurs in a temperate continental climate in a Brunic Arenosol forest, during dry summer periods. In control areas, the occurrence of hydrophobicity up to a severely repellent class (median value) was noted, while the maximum value of WDPT amounted to $10,800 \mathrm{~s}$.

The results allowed us to conclude that hydrophobicity in fire-affected soils, is dependent on the intensity of the fire, which has a significant impact on its occurrence. The extremely repellent class was observed in strong fire plots, in soil layers of up to $20 \mathrm{~cm}$ for a short period of time. After 13 months, the soil was once again found to be wettable.

The highest intensity and occurrence of SWR was observed in soil under older pines.

The largest spatial variation of SWR (5 classes), occurred in a layer of 10-20 cm on control plots affected by a moderate fire, and of low groundwater level 13 months after a fire.

The results confirmed the occurrence of SWR and necessitates the inclusion of this parameter in soil research, as a factor influencing processes that affect the stability and functions of the soil.

This study alone cannot explain the effects of SWR on runoff and sediment connectivity patterns, in the given study area. Additional research should clarify the influence of soil SWR on unstable infiltration, and the reason behind unwettability.

Author Contributions: The initiative and the conception of the article preparation belonged to E.H. E.H., L.O. and M.K., conducted field data collection and laboratory analyses. E.H., L.O., and D.G. provided expert knowledge used in data analysis and interpretation. E.H., I.O. and E.B.G. performed the investigation. All co-authors contributed to the writing of the manuscript.

Acknowledgments: This work was partially supported by the Forestry Fund LP in 2016 as a project "Physical, chemical properties of soils and diversity of plant, fungi and microfauna on a fire burnt area in Palmiry in the Kampinos National Park" We are also grateful to the staff of the Natural Park for their attention and assistance during part of the field work. Moreover, we would like to thank the students for their assistance in field and laboratory work. We thank the anonymous reviewer for her/his constructive comments and suggestions.

Conflicts of Interest: The authors declare no conflict of interest 


\section{References}

1. Breshears, D.D.; Cobb, N.S.; Rich, P.M.; Price, K.P.; Allen, C.D.; Balice, R.G.; Romme, W.H.; Kastens, J.H.; Floyd, M.L.; Belnap, J.; et al. Regional Vegetation Die-Off in Response to Global-Change-Type Drought. Proc. Natl. Acad. Sci. USA 2005, 102, 15144-15148. [CrossRef] [PubMed]

2. Allen, C.D.; Macalady, A.K.; Chenchouni, H.; Bachelet, D.; McDowell, N.; Vennetier, M.; Kitzberger, T.; Rigling, A.; Breshears, D.D.; Hogg, E.H.(T.); et al. A global overview of drought and heat-induced tree mortality reveals emerging climate change risks for forests. For. Ecol. Manag. 2010, 259, 660-684. [CrossRef]

3. Grossiord, C.; Granier, A.; Ratcliffe, S.; Bouriaud, O.; Bruelheide, H.; Chećko, E.; Forrester, D.I.; Dawud, S.M.; Finér, L.; Pollastrini, M.; et al. Tree diversity does not always improve resistance of forest ecosystems to drought. Proc. Natl. Acad. Sci. USA 2014, 111, 14812-14815. [CrossRef] [PubMed]

4. $\quad$ Lindner, M.; Fitzgerald, J.B.; Zimmermann, N.E.; Reyer, C.; Delzon, S.; van der Maaten, E.; Schelhaas, M.J.; Lasch, P.; Eggers, J.; van der Maaten-Theunissen, M.; et al. Climate change and European forests: What do we know, what are the uncertainties, and what are the implications for forest management? J. Environ. Manag. 2014, 146, 69-83. [CrossRef] [PubMed]

5. Neary, D.G.; Ice, G.G.; Jackson, C.R. Linkages between forest soils and water quality and quantity. For. Ecol. Manag. 2009, 258, 2269-2281. [CrossRef]

6. Goebel, M.O.; Bachmann, J.; Reichstein, M.; Janssens, I.A.; Guggenberger, G. Soil water repellency and its implications for organic matter decomposition-is there a link to extreme climatic events? Glob. Chang. Biol. 2011, 17, 2640-2656. [CrossRef]

7. Doerr, S.H.; Shakesby, R.A.; Walsh, R. Soil water repellency: Its causes, characteristics and hydro-geomorphological significance. Earth-Sci. Rev. 2000, 51, 33-65. [CrossRef]

8. Burcar, S.; Miller, W.W.; Johnson, D.W.; Tyler, S.W. Seasonal preferential flow in two Sierra Nevada soils under forested and meadow cover. Soil Sci. Soc. Am. J. 1994, 58, 1555-1561. [CrossRef]

9. Sevink, J.; Imeson, A.C.; Verstraten, J.M. Humus form development and hillslope runoff, and the effects of fire and management, under Mediterranean forest in NE-Spain. Catena 1989, 16, 461-475. [CrossRef]

10. Wang, C.; Shang, S.; Jia, D.; Han, Y.; Sauvage, S.; Sánchez-Pérez, J.-M.; Kuramochi, K.; Hatano, R. Integrated Effects of Land Use and Topography on Streamflow Response to Precipitation in an Agriculture-Forest Dominated Northern Watershed. Water 2018, 10, 633. [CrossRef]

11. Bauters, T.W.J.; Steenhuis, T.S.; DiCarlo, D.A.; Nieber, J.L.; Dekker, L.W.; Ritsema, C.J.; Parlangea, J.-Y.; Haverkamp, R. Physics of water repellent soils. J. Hydrol. 2000, 231, 233-243. [CrossRef]

12. Dekker, L. W.; Ritsema C., J. How water moves in a water repellent sandy soil: 1 . Potential and actual water repellency. Water Resour. Res. 1994, 30, 2507-2517. [CrossRef]

13. Urbanek, E.; Doerr, S.H. $\mathrm{CO}_{2}$ efflux from soils with seasonal water repellency. Biogeosciences 2017, $14,4781$. [CrossRef]

14. Hewelke, E.; Szatyłowicz, J.; Hewelke, P.; Gnatowski, T.; Aghalarov, R. The Impact of Diesel Oil Pollution on the Hydrophobicity and $\mathrm{CO}_{2}$ Efflux of Forest Soils. Water Air Soil Pollut. 2018, 229, 51. [CrossRef] [PubMed]

15. Mataix-Solera, J.; Arcenegui, V.; Guerrero, C.; Mayoral, A.M.; Morales, J.; González, J.; García-Orenes, F.; Gómez, I. Water repellency under different plant species in a calcareous forest soil in a semiarid Mediterranean environment. Hydrol. Process. 2007, 21, 2300-2309. [CrossRef]

16. Zavala, L.M.; González, F.A.; Jordán, A. Intensity and persistence of water repellency in relation to vegetation types and soil parameters in Mediterranean SW Spain. Geoderma 2009, 152, 361-374. [CrossRef]

17. Cerdà, A.; Borja, M.E.L.; Úbeda, X.; Martínez-Murillo, J.F.; Keesstra, S. Pinus halepensis M. versus Quercus ilex subsp. Rotundifolia L. runoff and soil erosion at pedon scale under natural rainfall in Eastern Spain three decades after a forest fire. For. Ecol. Manag. 2017, 400, 447-456. [CrossRef]

18. Gazol, A.; Camarero, J.J.; Jiménez, J.J.; Moret-Fernández, D.; López, M.V.; Sangüesa-Barreda, G.; Igual, J.M. Beneath the canopy: Linking drought-induced forest die off and changes in soil properties. For. Ecol. Manag. 2018, 422, 294-302. [CrossRef]

19. Szatylowicz, J.; Gnatowski, T.; Szejba, D.; Oleszczuk, R.; Brandyk, T.; Kechavarzi, C. Moisture content variability in drained fen soil. In Wetlands Modeling, Monitoring and Management; Okruszko, T., Maltby, E., Szatyłowicz, J., Świątek, D., Kotowski, W., Eds.; Taylor \& Francis Group: London, UK, 2007; pp. $113-120$. ISBN 978-0-415-4082. 
20. Lachacz, A.; Nitkiewicz, M.; Kalisz, B. Water repellency of post-boggy soils with a various content of organic matter. Biologia 2009, 64, 634-638. [CrossRef]

21. Kalisz, B.; Lachacz, A.; Glazewski, R. Effects of peat drainage on labile organic carbon and water repellency in NE Poland. Turk. J. Agric. For. 2015, 39, 20-27. [CrossRef]

22. Hewelke, E.; Szatyłowicz, J.; Gnatowski, T.; Oleszczuk, R. Spatial Variability in Soil Moisture Content under Preferential Flow in Hydrophobic Organic Soil. Rocz. Ochr. Środowiska 2014, 16, 580-607.

23. Hewelke, E.; Szatyłowicz, J.; Gnatowski, T.; Oleszczuk, R. Effects of soil water repellency on moisture patterns in a degraded sapric histosol. Land Degrad. Dev. 2016, 27, 955-964. [CrossRef]

24. Glina, B.; Bogacz, A.; Gulyás, M.; Zawieja, B.; Gajewski, P.; Kaczmarek, Z. The effect of long-term forestry drainage on the current state of peatland soils: A case study from the Central Sudetes (SW Poland). Mires Peat 2016, 18, 1-11.

25. Buczko, U.; Bens, O.; Fischer, H.; Hüttl, R.F. Water repellency in sandy luvisols under different forest transformation stages in northeast Germany. Geoderma 2002, 109, 1-18. [CrossRef]

26. Buczko, U.; Bens, O.; Hüttl, R.F. Variability of soil water repellency in sandy forest soils with different stand structure under Scots pine (Pinus sylvestris) and beech (Fagus sylvatica). Geoderma 2005, 126, 317-336. [CrossRef]

27. Doerr, S.H.; Shakesby, R.A.; Dekker, L.W.; Ritsema, C.J. Occurrence, prediction and hydrological effects of water repellency amongst major soil and land-use types in a humid temperate climate. Eur. J. Soil Sci. 2006, 57, 741-754. [CrossRef]

28. Greiffenhagen, A.; Wessolek, G.; Facklam, M.; Renger, M.; Stoffregen, H. Hydraulic functions and water repellency of forest floor horizons on sandy soils. Geoderma 2006, 132, 182-195. [CrossRef]

29. Orfánus, T.; Dlapa, P.; Fodor, N.; Rajkai, K.; Sándor, R.; Nováková, K. How severe and subcritical water repellency determines the seasonal infiltration in natural and cultivated sandy soils. Soil Tillage Res. 2014, 135, 49-59. [CrossRef]

30. Lichner, L.; Capuliak, J.; Zhukova, N.; Holko, L.; Czachor, H.; Kollár, J. Pines influence hydrophysical parameters and water flow in a sandy soil. Biologia 2013, 68, 1104-1108. [CrossRef]

31. Buczko, U.; Bens, O.; Hüttl, R.F. Changes in soil water repellency in a pine-beech forest transformation chronosequence: Influence of antecedent rainfall and air temperatures. Ecol. Eng. 2007, 31, 154-164. [CrossRef]

32. Doerr, S.H.; Shakesby, R.A.; MacDonald, L.H. Soil water repellency: A key factor in post-fire erosion. In Fire Effects on Soils and Restoration Strategies; Cerda, A., Peter, R.R., Eds.; CRC Press: Boca Raton, FL, USA, 2009; Volume 5, ISBN 9781578085262.

33. DeBano, L.F. The role of fire and soil heating on water repellency in wildland environments: A review. J. Hydrol. 2000, 231, 195-206. [CrossRef]

34. Jordán, A.; Zavala, L.M.; Mataix-Solera, J.; Nava, A.L.; Alanís, N. Effect of fire severity on water repellency and aggregate stability on Mexican volcanic soils. Catena 2011, 84, 136-147. [CrossRef]

35. Arcenegui, V.; Mataix-Solera, J.; Guerrero, C.; Zornoza, R.; Mataix-Beneyto, J.; García-Orenes, F. Immediate effects of wildfires on water repellency and aggregate stability in Mediterranean calcareous soils. Catena 2008, 74, 219-226. [CrossRef]

36. Granged, A.J.; Jordán, A.; Zavala, L.M.; Bárcenas, G. Fire-induced changes in soil water repellency increased fingered flow and runoff rates following the 2004 Huelva wildfire. Hydrol. Process. 2011, 25, 1614-1629. [CrossRef]

37. Zavala, L.M.; González, F.A.; Jordán, A. Fire-induced soil water repellency under different vegetation types along the Atlantic dune coast-line in SW Spain. Catena 2009, 79, 153-162. [CrossRef]

38. Mataix-Solera, J.; Arcenegui, V.; Tessler, N.; Zornoza, R.; Wittenberg, L.; Martínez, C.; Caselles, P.; Pérez-Bejarano, A.; Malkinson, D.; Jordán, M.M. Soil properties as key factors controlling water repellency in fire-affected areas: Evidences from burned sites in Spain and Israel. Catena 2013, 108, 6-13. [CrossRef]

39. MacDonald, L.H.; Huffman, E.L. Post-fire soil water repellency. Soil Sci. Soc. Am. J. 2004, 68, $1729-1734$. [CrossRef]

40. Malkinson, D.; Wittenberg, L. Post fire induced soil water repellency-Modeling short and long-term processes. Geomorphology 2011, 125, 186-192. [CrossRef] 
41. Bodí, M.B.; Muñoz-Santa, I.; Armero, C.; Doerr, S.H.; Mataix-Solera, J.; Cerdà, A. Spatial and temporal variations of water repellency and probability of its occurrence in calcareous Mediterranean rangeland soils affected by fires. Catena 2013, 108, 14-25. [CrossRef]

42. Bowman, D.M.J.S.; Balch, J.K.; Artaxo, P.; Bond, W.J.; Carlson, J.M.; Cochrane, M.A.; D'Antonio, C.M.; DeFries, R.S. Fire in the Earth system. Science 2009, 324, 481-484. [CrossRef] [PubMed]

43. Thompson, M.P.; Scott, J.; Langowski, P.G.; Gilbertson-Day, J.W.; Haas, J.R.; Bowne, E.M. Assessing Watershed-Wildfire Risks on National Forest System Lands in the Rocky Mountain Region of the United States. Water 2013, 5, 945-971. [CrossRef]

44. Pausas, J.G. Changes in fire and climate in the eastern Iberian Peninsula (Mediterranean basin). Clim. Chang. 2004, 63, 337-350. [CrossRef]

45. Stojanovic, M.; Drumond, A.; Nieto, R.; Gimeno, L. Anomalies in Moisture Supply during the 2003 Drought Event in Europe: A Lagrangian Analysis. Water 2018, 10, 467. [CrossRef]

46. Boczoń, A.; Kowalska, A.; Dudzińska, M.; Wróbel, M. Drought in Polish Forests in 2015. Pol. J. Environ. Stud. 2016, 25, 1857-1862. [CrossRef]

47. Hewelke, P.; Gnatowski, T.; Hewelke, E.; Tyszka, J.; Zakowicz, S. Analysis of Water Retention Capacity for Select Forest Soils in Poland. Pol. J. Environ. Stud. 2015, 24, 1013-1019. [CrossRef]

48. European Commission. Forest Fires in Europe, Middle East and North Africa 2015; Joint Research Centre: Ispra, Italy, 2016; p. 117. ISBN 978-92-79-62958-7.

49. Niklasson, M.; Zin, E.; Zielonka, T.; Feijen, M.; Korczyk, A.F.; Churski, M.; Samojlik, T.; Jedrzejewska, B.; Gutowski, J.M.; Brzeziecki, B. A 350-year tree-ring fire record from Białowieża Primeval Forest, Poland: Implications for Central European lowland fire history. J. Ecol. 2010, 98, 1319-1329. [CrossRef]

50. Krogulec, E.; Zabłocki, S. Relationship between the environmental and hydrogeological elements characterizing groundwater-dependent ecosystems in central Poland. Hydrogeol. J. 2015, 23, 1587-1602. [CrossRef]

51. Krogulec, E. Evaluating the risk of groundwater drought in groundwater-dependent ecosystems in the central part of the Vistula River Valley, Poland. Ecohydrol. Hydrobiol. 2018, 18, 82-91. [CrossRef]

52. Ryżak, M.; Bartminski, P.; Bieganowski, A. Methods for determination of particle size distribution of mineral soils [in Polish]. Acta Agrophys. 2009, 175, 1-84.

53. Soil Survey Division Staff. Soil Survey Manual; United States Department of Agriculture: Washington, DC, USA, 1993; p. 315.

54. Food and Agriculture Organizaiton of the United Nations (FAO); International Union of Soil Sciences (IUSS). World Reference Base for Soil Resources 2014, International Soil Classification System for Naming Soils and Creating Legends for Soil Maps; Food and Agriculture Organizaiton of the United Nations (FAO): Rome, Italy, 2015; p. 192. ISBN 978-92-5-108369-7.

55. Olszewski, A.; Wierzbicki, A.; Lenartowicz, M. Report from the Realization of a Research-Measurement Programme-Integrated Monitoring of the Natural Environment at the Kampinos Base Station in 2016; Kampinoski Park Narodowy: Granica, Poland, 2017; p. 188. (In Polish)

56. Rodríguez-Alleres, M.; Benito, E. Temporal fluctuations of water repellency in forest soils of Galicia, NW Spain. Do soil samples dried at laboratory reflect the potential soil water repellency? Hydrol. Process. 2012, 26, 1179-1187. [CrossRef]

57. Papierowska, E.; Matysiak, W.; Szatyłowicz, J.; Debaene, G.; Urbanek, E.; Kalisz, B.; Łachacz, A. Compatibility of methods used for soil water repellency determination for organic and organo-mineral soils. Geoderma 2018, 314, 221-231. [CrossRef]

58. Dekker, L.W.; Jungerius, P.D. Water repellency in the dunes with special reference to The Netherlands. Catena Suppl. 1990, 18, 173-183.

59. González-Pérez, J.A.; González-Vila, F.J.; Almendros, G.; Knicker, H. The effect of fire on soil organic matter-A review. Environ. Int. 2004, 30, 855-870. [CrossRef] [PubMed]

60. Badía, D.; López-García, S.; Martí, C.; Ortíz-Perpiñá, O.; Girona-García, A.; Casanova-Gascón, J. Burn effects on soil properties associated to heat transfer under contrasting moisture content. Sci. Total. Environ. 2017, 601, 1119-1128. [CrossRef] [PubMed]

61. Molla, I.; Velizarova, E.; Malcheva, B.; Bogoev, V.; Hadzhieva, Y. Forest Fire Impact on the Soil Carbon Content and Stock on the North Slopes of Rila Mountain (Bulgaria). Ecol. Balck 2014, 2014. 5, 81-88.

62. Certini, G. Effects of fire on properties of forest soils: A review. Oecologia 2005, 143, 1-10. [CrossRef] [PubMed] 
63. Rodríguez-Alleres, M.; Varela, M.E.; Benito, E. Natural severity of water repellency in pine forest soils from NW Spain and influence of wildfire severity on its persistence. Geoderma 2012, 191, 125-131. [CrossRef]

64. Santos, J.M.; Verheijen, F.G.A.; Wahren, F.T.; Wahren, A.; Feger, K.H.; Jannin, L.B.; Rial-Rivas, M.E.; Keizer, J.J.; Nunes, J.P. Soil water repellency dynamics in pine and eucalypt plantations in Portugal a high-resolution time series. Land Degrad. Dev. 2013, 27, 1334-1343. [CrossRef]

65. Gabarrón-Galeote, M.A.; Martínez-Murillo, J.F.; Quesada, M.A.; Ruiz-Sinoga, J.D. Seasonal changes in the soil hydrological and erosive response depending on aspect, vegetation type and soil water repellency in different Mediterranean microenvironments. Solid Earth 2013, 4, 497. [CrossRef]

66. Täumer, K.; Stoffregen, H.; Wessolek, G. Determination of repellency distribution using soil organic matter and water content. Geoderma 2005, 125, 107-115. [CrossRef]

67. Neary, D.G.; Klopatek, C.C.; DeBanoc, L.F.; Ffolliott, P.F. Fire effects on belowground sustainability: A review and synthesis. For. Ecol. Manag. 1999, 122, 51-71. [CrossRef]

68. Vogelmann, E.S.; Reichert, J.M.; Prevedello, J.; Consensa, C.O.B.; Oliveira, A.É.; Awe, G.O.; Mataix-Solera, J. Threshold water content beyond which hydrophobic soils become hydrophilic: The role of soil texture and organic matter content. Geoderma 2013, 209, 177-187. [CrossRef]

69. Huffman, E.L.; MacDonald, L.H.; Stednick, J.D. Strength and persistence of fire-induced soil hydrophobicity under ponderosa and lodgepole pine, Colorado Front Range. Hydrol. Process. 2001, 15, 2877-2892. [CrossRef]

70. Ganz, C.; Bachmann, J.; Lamparter, A.; Woche, S.K.; Duijnisveld, W.H.; Göbel, M.O. Specific processes during in situ infiltration into a sandy soil with low-level water repellency. J. Hydrol. 2013, 484, 45-54. [CrossRef]

71. Mataix-Solera, J.; Doerr, S.H. Hydrophobicity and aggregate stability in calcareous topsoils from fire-affected pine forest in southeastern Spain. Geoderma 2004, 118, 77-88. [CrossRef]

72. Doerr, S.H.; Shakesby, R.A.; Walsh, R. Soil hydrophobicity variations with depth and particle size fraction in burned and unburned Eucalyptus globulus and Pinus pinaster forest terrain in the Agueda Basin, Portugal. Catena 1996, 27, 25-47. [CrossRef]

73. Rodríguez-Alleres, M.; Benito, E.; de Blas, E. Extent and persistence of water repellency in north-western Spanish soils. Hydrol. Process. 2007, 21, 2291-2299. [CrossRef]

74. Butzen, V.; Seeger, M.; Marruedo, A.; de Jonge, L.; Wengel, R.; Ries, J.B.; Casper, M.C. Water repellency under coniferous and deciduous forest-Experimental assessment and impact on overland flow. Catena 2015, 133, 255-265. [CrossRef]

75. Cerdà, A.; Doerr, S.H. Soil wettability, runoff and erodibility of major dry-Mediterranean land use types on calcareous soils. Hydrol. Process. 2007, 21, 2325-2336. [CrossRef]

76. Pereira, P.; Úbeda, X.; Martin, D.; Mataix-Solera, J.; Cerdà, A.; Burguet, M. Wildfire effects on extractable elements in ash from a Pinus pinaster forest in Portugal. Hydrol. Process. 2014, 28, 3681-3690. [CrossRef]

77. Wallis, M.G.; Horne, D.J. Soil water repellency. In Advances in Soil Science; Stewart, B.A., Ed.; Springer: New York, NY, USA, 1992; pp. 91-146. ISBN 978-1-4612-3144-8.

78. Alanís, N.; Hernández-Madrigal, V.M.; Cerdà, A.; Muñoz-Rojas, M.; Zavala, L.M.; Jordán, A. Spatial gradients of intensity and persistence of soil water repellency under different forest types in central Mexico. Land Degrad. Dev. 2017, 28, 317-327. [CrossRef]

79. Olejniczak, I.; Gorska, E.B.; Kondras, M.; Oktaba, L.; Gozdowski, D.; Jankiewicz, U.; Prędecka, A.; Dobrzyński, J.; Otręba, A.; Tyburski, Ł.; et al. Fire-a Factor Forming the Numbers of Microorganisms and Mesofauna in Forest Soils. Rocz. Ochr. Środowiska 2017, 19, 511-526.

80. Zaniewski, P.T.; Otreba, A. Response of vegetation to the surface fire in the pine forest Peucedano-Pinetum W. Mat. (1962) 1973 in the Kampinoski National Park. Sylwan 2017, 161, 991-1001.

81. Stocker, T.F.; Qin, D.; Plattner, G.-K.; Tignor, M.; Allen, S.K.; Boschung, J.; Nauels, A.; Xia, Y.; Bex, V.; Midgley, P.M. Contribution of Working Group I to the Fifth Assessment Report of the Intergovernmental Panel on Climate Change. In Climate Change 2013: The Physical Science Basis; IPCC (Intergovernmental Panel on Climate Change): Geneva, Switzerland; Cambridge University Press: Cambridge, UK, 2013.

(C) 2018 by the authors. Licensee MDPI, Basel, Switzerland. This article is an open access article distributed under the terms and conditions of the Creative Commons Attribution (CC BY) license (http:/ / creativecommons.org/licenses/by/4.0/). 